Uşak Üniversitesi Sosyal Bilimler Dergisi

$2014,7 / 2$

\title{
Altıncı Sınıf Öğrencilerinin Dinleme Becerilerinin Taşımalılık Değişkeni Açısından Değerlendirilmesi
}

\author{
Talat AYTAN* \\ Nail GÜNEY** \\ Esin Yağmur ŞAHIIN*** \\ Adem BAYAR ${ }^{* * *+*}$
}

\begin{abstract}
Özet
Dinleme, duyma mekanizmalarından geçen bilgilerin kaydedilip kullanıma hazır hâle gelmesini sağlayan bir farkındalıktır. Duymanın ötesinde aktif bir zihinsel yöntemdir. Taşımalı eğitim; nüfusu az ve dağınık olan yerleşim birimlerinde bulunan ilköğretim çağındaki öğrencilerin merkez olarak seçilen ilköğretim kurumlarına günü birlik taşınması suretiyle eğitimöğretim görmesi sürecidir. Türkiye'de 1989-1990 eğitim-öğretim yllının ikinci yarısından itibaren taşımalı eğitim uygulamasına geçilmiş; 2011-2012 eğitim-öğretim yılında ilkokul, ortaokul ve liselerin tamamı bu uygulamaya dâhil edilmiştir. Eğitim niteliğinin yükseltilmesi, fırsat eşitliğinin sağlanması ve maliyetlerin azaltılması gibi nedenlerle yürürlüğe konan taşımalı eğitimin olumsuz yönlerinden biri öğrenciler üzerindeki fiziksel yorgunluğun öğrenme üzerindeki etkisidir.

$\mathrm{Bu}$ araştırma, ilköğretim altıncı sınıf öğrencilerinin dinleme becerilerini taşımalılık değişkeni açısından değerlendiren deneysel bir çalışmadır. Alan uzmanlarının görüşleri doğrultusunda hazırlanan dokuz maddelik dinleme başarı testi, 2011-2012 eğitim-öğretim yılında Trabzon ili Akçaabat ilçesindeki ilköğretim okullarından birinde 6/A ve 6/B sınıflarında öğrenim gören 23'ü taşımalı 46 öğrenciye uygulanmıştır.

Deneysel süreç sonunda akademik başarı yönünden yerleşik öğrenciler lehinde anlamlı farklılık oluşmuştur. Bu sonuç, taşımalı öğrencilerin taşıma sürecindeki fiziksel ve zihinsel yorgunluğunun dinlediğini anlama
\end{abstract}

"Yrd. Doç. Dr., Yıldız Teknik Üniversitesi, Eğitim Fakültesi Türkçe Eğitimi Bölümü taytan@yildiz.edu.tr

${ }^{*}$ Yrd. Doç. Dr., Canik Başarı Üniversitesi, Eğitim Fakültesi Türkçe Eğitimi Bölümü nguney@basari.edu.tr

${ }^{* * *}$ Yrd. Doç. Dr., Çanakkale On Sekiz Mart Üniversitesi, Eğitim Fakültesi Türkçe Eğitimi Bölümü esinsahin25@gmail.com

${ }^{* * * *}$ Yrd. Doç. Dr. Amasya Üniversitesi, Eğitim Fakültesi Eğitim Yönetimi ve Denetimi Bölümü adembayar80@gmail.com 
üzerindeki olumsuz etkisini ortaya koymaktadır. Bu itibarla taşımalı öğrencilerin bulunduğu okullarda dil, matematik, fen ve sosyal bilgiler gibi aktif dinleme gerektiren derslerin öğleden önce; beden eğitimi, müzik ve resim gibi spor ve sanat derslerinin ise öğleden sonra işlenmesi faydalı olacaktır.

Anahtar sözcükler: Dinleme becerisi, taşımalılık, yerleşiklik, başarı.

\title{
The Evaluation Of Listening Abilities Of 6th Class Students In Terms Of Transportational Parameter
}

\begin{abstract}
Listening is an awareness that provides the storage and usage of the knowledge passing from hearing mechanisms. It is an active mental method beyond hearing. Transportational education is an education process in which primary school students coming from less and non-intensive populated regions are transported each day to the selected primary school foundations as center. In Turkey, in the second semester of 1989-1990 education year, transportational education practice was started; and in 20112012 education year all primary, secondary and high schools were included in that practice. One of the negative points of transportational education which was brought into practice to develop the quality of education, to provide equality of opportunity and to diminish the costs is the influence of physical exhaustion of students in learning process.

This study is an experimental research on $6^{\text {th }}$ class students' listening abilities in terms of transportational parameter. Listening success test prepared by the help of related experts' opinions was applied to 46 students including 23 transportational ones who are studying at one of Trabzon(City) Akçabat(Town) Primary Schools in 6/A and 6/B classes.

At the end of the experimental process, a meaningful difference in terms of academic success was observed in favor of settled students. This outcome exhibits that the physical and mental exhaustion of transportational students in the process of transportation have negative effects to understand what is listened. In this respect, it would be useful to give language, mathematics, science and social science courses which require active listening before afternoon; and physical education, music and art courses in the afternoon at schools including transportational students.
\end{abstract}

Key words: Listening ability, transportational, settled, success. 


\section{Giriş}

Dinleme, duyma mekanizmalarından geçen bilgilerin kaydedilip kullanıma hazır hâle gelmesini sağlayan bir farkındalıktır. Bu açıdan dinleme, duymanın ötesinde aktif bir zihinsel yöntemdir. Dinleme becerisinin gelişmeye başlaması doğum öncesine kadar uzanmaktadır. Anne karnındaki bebeğin dişarıdan gelen seslere karşı tepkisi özellikle hamileliğin son dönemlerinde kendini göstermektedir (Healy, 1999: 46, Robertson, 2004: 57).

Dinleme, çocuğun ilk ana dili etkinliğidir ve çocuk okul öncesinde bilgilerin çoğunu dinleme yoluyla öğrenir (Özdemir, 1987: 166). Çocuğun dinleme becerisi informal bir ortamda ailenin ya da çevrenin etkisiyle gelişmektedir. Planlı bir eğitim yoktur, ailenin çabasıyla doğru orantılı olarak gelişir. Dinleme, okula başladığında da çocuğun temel öğrenme araçlarından biridir. Dil eğitiminin temelleri dinleme eğitimiyle atılır. Diğer dil etkinlikleri ise dinleme etkinliğinin üzerine gelişip biçimlenir (Çelenk, 2005: 135).

Dinleme becerisi, alan uzmanlarınca farklı şekillerde tanımlanmaktadır:

- Sözlü iletişim sürecinde etkili anlama ve cevap verme yeteneği (Johnson, 1951: 58).

- Konuşulan kelimelere dikkat etmek, seslerin yanı sıra onları anlamak (Hampleman, 1958: 49).

- İşitmeyi, anlamayı, anlaşılan bilgileri önceki bilgilerle bütünleştirmeyi ve gerekirse cevap vermeyi içeren aktif bir süreç (Wolff, Marsnik, Tacey ve Nichols, 1983).

- Her gün hiç düşünmeden, çevremizde olup biteni anlamlandırmak için kullandığımız bir dil becerisi (Rost, 1994: 1).

- Mesaja yoğunlaşmak için işitilenlerden pek çoğunu zihinsel bir süzgeçten geçirme, işitmeden çok daha öte bir iş (Jalongo, 1995: 13).

- Konuşmayı, kıpırdamayı, çeşitli konularda dolaşan zihni durdurmak ve konuşanın söylediklerine kilitlenmek (Moore, 120).

- Seslerin ve varsa konuşma görüntülerinin farkında olmayla ve onlara dikkati vermeyle başlayan, belli işitsel işaretlerin tanınması ve hatırlanmasıyla süren ve anlamlandırılmasıyla son bulan psikolojik bir süreç (Ergin ve Birol, 2000: 115).

- Dinleme, sözel bir girdiyi anlama ve yorumlama sürecidir. Dinleme, anlamaya dayalı, birçok işlemin bir arada, etkileşimsel olarak gerçekleştiği bir edimdir (Keçik ve Uzun, 2004: 111). 
- Dinleme, konuşan ya da sesli okuyan bir kişinin vermek istediği sözlü mesajları doğru olarak anlayabilme etkinliğidir (Özbay, 2005: 11).

- Dinleme, konuşma dilinin zihinde anlama dönüştürüldüğü karmaşık ve çok aşamalı bir süreçtir (akt. Akyol, 2010: 1).

- Dinleme; iletileri anlayabilme, uyarana tepkide bulunabilme etkinliğidir. Diğer bir deyişle dinleme, konuşma ve ya da okuma yoluyla gönderilen bir iletinin kavranmasıdır (Gürgen, 2008: 49).

- Dinleme, dinleyicinin önce söylenilenlerle sonra söylenilenler arasında bağlantı kurma ve iletişim içindeki işlevini anlama yeteneğidir (Temur, 2001: 61).

- İşittiğimizi anlamak ve saklamaktır (Kantemir, 1997: 12).

Dinleme, temel dil becerileri arasında günlük yaşamda en fazla kullanılanıdır. Minnesota Üniversitesi'nden Dr. Lyman K. Steil'in yaptığ dinleme ile ilgili araştırmalarda insanların her gün iletişime ayırdıkları sürenin \%9'unda yazı yazdıkları, \%16'sında okudukları, \%30'unda konuştukları ve \%45'inde ise dinledikleri ortaya çıkmıştır (Ailes, 1996: 69).

Yangın (1998), “Dinlediğini Anlama Becerisini Geliştirmede Elves Yönteminin Etkisi"adlı doktora tezinde İngilizce "Excite", "Listen" , "Visualize","Extend" ve "Savor" kelimelerinin ilk harflerinin birleşmesinden meydana gelen ELVES yöntemini ilkokul birinci sinıf öğrencilerine uygulamıştır. Araştırma, deney ve kontrol gruplu bir deneysel çalışmadır. Deney grubunda on hafta boyunca ELVES yöntemiyle dinleme çalışmaları yapılmış, kontrol grubuna herhangi bir dinleme eğitimi verilmemiştir. Uygulama sonucunda deney grubunun başarı puanları kontrol grubunun başarı puanlarından daha anlamlı bir artış göstermiştir. Yazkan (2000),“ilköğretim Okullarının I. Kademesinde Dinlediğini Anlama Davranışının Kazandırılmasına Dramatizasyonun Etkisi”adlı yüksek lisans tezinde ilköğretim üçüncü ve dördüncü sınıfta öğrenim gören 428 öğrenci üzerinde dramatizasyon çalışmalarının dinleme becerisi üzerindeki etkilerini araştırmıştır. Araştırma bulguları; dramatizasyonun anlamayı ve hatırlamayı kolaylaştırdığı, dinlediğini anlama davranışının kazanılmasında okuma yöntemine göre daha etkili olduğu; kız öğrencilerin öznel anlatımlı ve duygu değeri taşıyan metinleri erkek öğrencilere göre daha iyi anladıkları yönündedir. Cihangir (2000), “Üniversite Öğrencilerine Verilen Etkin Dinleme Becerisi Eğitiminin Başkalarını Dinleme Becerilerine Etkisi"adlı yüksek lisans tezinde etkin dinleme becerilerine yönelik bir eğitim programı geliştirmiştir. Programın üniversite birinci sınıf öğrencilerinin başkalarını 
dinleme üzerindeki etkisini araştırmıştır. Deney grubuna on hafta süresince adı geçen eğitim programı uygulanmış, kontrol grubuna herhangi bir dinleme uygulaması yapılmamıştır. Araştırma sonucunda uygulanan eğitim programının deney grubundaki üniversite öğrencilerinin dinleme becerilerini olumlu yönde etkilediği ortaya çıkmıştır. Yaşlı (2001), "Öğrenmede Empatik Dinleme ve Öğrenme Güdülenmesine Etkisi" adlı yüksek lisans tezinde empatik dinlemeyi benimsemiş öğretmen modelinin öğrencilerin öğrenmeye güdülenmesi üzerindeki etkilerini araştırmıştır. Empatik dinlemeyi gerçekleştiren öğretmenler ile beklenti içinde ya da yargılayıcı dinleyen öğretmen modelleri karşılaştırılmıştır.Kaygas (2002), "Üniversite Son Sınıf Öğrencilerinin Okuma ve Dinleme Sonucu Anladıklarını Yazılı Anlatma Becerileri" adlı yüksek lisans tezinde öğrencilerin, dinleme sonucu anladıklarını yazılı olarak ifade etmede okumadan daha başarılı olduğu sonucuna varmıştır. Kaplan (2002), “İlköğretim 6.Sınıf Öğrencilerinin Dinleme Becerileri Üzerine Bir Araştırma" adlı yüksek lisans tezinde farklı yazılı anlatım türlerinden on iki metin okunan, bu metinlerle ilgili muhtelif dinleme etkinlikleri yaptırlan öğrencilerin dinleme testinden aldıkları puanların arttığı ortaya konmaktadır. Ayrıca dinleme etkinliklerinde görsel-işitsel araçların öğrenci dikkatini azami derecede artırdığı dile getirilmektedir. Köklü (2003), “Türkçe Öğretiminde 7. ve 8. sınıf Öğrencilerine Dinlediğini Anlama Davranışının Kazandırılmasına Dramatizasyonun Etkisi" adlı yüksek lisans tezinde eğitici dramanın 7. sınıfta şiir, 8. sınıfta öykü türünden bir metnin anlaşılmasında ve hatırlanmasında düz okuma tekniğine göre daha etkili olduğunu tespit etmiştir. Eğitici drama tekniklerinin, dinlediğini anlamada ve hatırlamada öğrencilerin başarı seviyelerini olumlu yönde etkilediği sonucuna varmıştır. Koç (2003), “Dinleme Becerilerini Kazandırma Yöntemlerinin Uygulanması" adlı yüksek lisans tezinde, dinleme becerisi kazandırma yöntemlerini ilköğretim beşinci sınıf öğrencilerine uygulamıştır. Araştırma sonunda, dinleme becerisi kazandırma yöntemlerinin uygulandığı deney grubu öğrencileri, kontrol grubu öğrencilerinden daha başarılı bulunmuştur. Uygulamada kullanılan yöntemlerden en başarılısı "dramatizasyon" olmuştur. Aras (2004), "İlköğretimde Dinleme Anlama Becerisinin Geliştirilmesi"adlı yüksek lisans tezinde sosyo-ekonomik yönden farklı üç ilköğretim okulundaki ikinci kademe öğrencileri üzerinde çalışmıştır. Okuduğunu anlama testine tabi tutulan öğrencilerin seviyelerine uygun metinler sınıflarda işlenmiş, dersten sonra da öğrencilere dinlediğini anlama testi uygulanmıştır. Araştırmada, sınıf seviyesi yükseldikçe başarının yükseldiği; başarı durumunun öğrencilerin sosyo-ekonomik durumuyla doğru orantılı olduğu sonucuna varılmıştır. Doğan (2007),“İlköğretim İkinci 
Kademede Dil Becerisi Olarak Dinlemeyi Geliştirme Çalışmaları" adlı doktora tezinde öğrencilerin dinleme düzeylerini belirlemek amacıyla alan uzmanlarının görüssleri de alınarak on maddeden oluşan bir Dinleme Testi hazırlamıştır. Uygulama, yedinci sınıf öğrencilerine yöneliktir. Yapılan ön test sonucunda deney grubuna dört hafta boyunca haftada ikişer saat uygulamalı eğitim verilmiştir. Bu eğitim sırasında öğrencilere dinleme öncesi, sırası ve sonrasında dikkat etmeleri gereken noktalar, dinlerken not alma teknikleri vb. konularda bilgiler verilmiştir. Bu bilgiler, örnekler üzerinde uygulamalı olarak gösterilmiştir. Kontrol grubundaki öğrencilerle dersler önceden olduğu gibi klasik şekilde işlenmiştir. Eğitim çalışmalarından sonra her iki grubun da ortalama puanlarında bir artış görülmüştür; ancak deney grubundaki öğrencilerin puan ortalamasındaki artış, kontrol grubundaki öğrencilerin puan ortalamasındaki artıştan belirgin derecede fazla olmuştur. Yıldırım (2007), "İlköğretim 3. Sınıf Öğrencilerinin Dinleme Becerileri Üzerine Bir Araştırma" adlı yüksek lisans tezinde dinleme becerilerini geliştirmeye yönelik çeşitli yöntem ve tekniklerle yapılan bir uygulamanın ilköğretim üçüncü sınıf öğrencilerinin dinleme becerileri üzerindeki etkisini araştırmıştır. Araştırmada öğrencilerin dinleme becerilerinin geliştiği, erkek öğrencilerin kız öğrencilere nazaran daha başarılı olduğu, ana okuluna gitmiş öğrencilerin dinleme başarı puanlarının daha yüksek olduğu, ebeveyn öğrenim durumlarının başarıda etkili olduğu, çalışan annelerin çocuklarının daha başarılı olduğu, ailenin maddi durumunun öğrenci başarısında etkili olmadığı sonuçlarına varılmıştır. Yılmaz (2007), “Türkçe Öğretiminde Dinleme Becerisini Geliştirmeye Yönelik Önerilen Etkinliklerin Değerlendirilmesi" adlı yüksek lisans tezinde altıncı sınıf öğrencilerinden deney grubuna Dinleme-İzleme, Dinleme-Yeniden Yapılandırma, Dinleme-Müzik, Dinleme-Boşluk Doldurma, Dinleme-Haber, Dinleme-Not Tutma Etkinlikleri uygulamıştır. Kontrol grubuna ise geleneksel yöntemle dinleme çalışmaları yapılmıştır. Yapılan son testte deney grubunun başarısı kontrol grubundan daha yüksek olmuştur ve bu tür etkinliklerin, öğrencilerin etkili dinleme becerisini geliştirdiği görülmüştür. Çelebi (2008), “Ilköğretim 6, 7 ve 8 . Sınıf Öğrencilerinin Olay ve Düşünce Yazılarına Göre Dinleme Becerilerinin Değerlendirilmesi" adlı yüksek lisans tezinde 6, 7 ve 8. sınıf öğrencilerinin düşünce ve olay yazılarına göre dinlediğini anlama becerilerini belirlemek amaciyla, 205'i erkek, 200'ü kız olmak üzere toplam 405 ilköğretim öğrencisine olay ve düşünce yazıları ile ilgili başarı testi ve bilgi toplama formu uygulamıştır. Öğrencilerin olay yazılarını dinleme ve anlama 
düzeylerinin düşünce yazılarını anlama düzeylerine göre daha yüksek olduğu, her iki yazı türünde de kız öğrencilerin daha başarılı olduğu, ebeveyn öğrenim durumlarının ve aylık gelirlerinin anlama düzeyleri arasında doğrudan bir ilişki olduğu sonuçlarına ulaşılmıştır. Kurt (2008), “Çocuk Edebiyatı Ürünlerinin Temel Dil Becerisi Olarak Dinlemenin Gelişimine Etkisi" adlı yüksek lisans tezinde çocuk edebiyatı açısından uygun olduğu varsayılan metinler ve böyle bir varsayımdan uzak metinlerin dinleme becerisine olumlu ya da olumsuz etkisinin belirlenmesi amaçlanmıştır. Araştırmada, uygun edebî metinlerin uygun olmayan edebî metinlere göre öğrencilerin dinleme becerisini daha yüksek düzeyde geliştirdiği, okulun bulunduğu yerleşim yeri, cinsiyet gibi değişkenlerle dinleme başarıları arasında doğrudan bir ilişki olduğu sonuçlarına ulaşılmıştır. Çelikbaş (2010), "Anlama/Dinleme Stratejilerinin Kullanımı ile Dinlediğini Anlama Düzeyi Arasındaki İlişki"adlı yüksek lisans tezinde yedinci sınıf öğrencilerinden deney grubuna dinleme stratejileri sistemli bir şekilde öğretilmiş, kontrol grubuna strateji eğitimi verilmemiştir. Son test ile “Dinleme Becerilerini Değerlendirme Ölçeği” uygulanmış, öğrencilerin ön test ve son test değerleri arasında anlamlı bir fark olup olmadığ 1 incelenmiştir. Deney grubunun başarısının yüksek olduğu araştırmada, dinleme başarısında cinsiyet, ana sınıfına devam etme, anne öğrenim durumu gibi değişkenlerin etkili olmadığı sonucuna ulaşılmıştır (Aktaran Aytan, 2011).

\section{Araştırmanın Amacı ve Önemi}

Türkiye'de taşımalı eğitim; zorunlu eğitim süresinin artırılmasıyla beraber yaygınlaşan, anayasada ifadesini bulan eğitim hakkının uygulanması amacıyla, "nüfusu az ve dağınık yerleşim birimlerinde bulunan ilköğretim çağındaki öğrencilerin merkez olarak seçilen ilköğretim kurumlarına günü birlik taşınarak eğitim-öğretim verilmesini amaçlamaktadır. Taşımalı eğitimin yaygınlaştırılmasında önemli etkenlerden biri de eğitim maliyetlerinin düşürülmeye çalışılmasıdır.

MEB 1989-1990 eğitim-öğretim yılının ikinci yarısından itibaren taşımalı eğitim uygulamasına geçmiş ve bu uygulama 2006-2007 eğitimöğretim yılında tüm ülkeye yayılmıştır. 2010-2011 eğitim-öğretim yılında 9. sinıflar, 2011-2012 için eğitim-öğretim yılında 9. ve 10. sinıflar, 2012-2013 eğitim öğretim yılında ise liselerin tamamı bu uygulamaya dâhil edilmiştir (MEB, 2012).

ABD, Yeni Zelanda, Avustralya, Rusya'da taşımalı eğitim farklı şekillerde uygulanmıştır. Dünyadaki taşımalı eğitim uygulamalarına genel olarak bakıldığında; Yeni Zelanda'da, okul öncesi eğitim için; ABD'de lise 
öğrencilerinin okuma, İngilizce ve matematik konularında yetiştirilmesinde; Avustralya'da ise geniş yüz ölçümünde dağınık olarak yaşayan, zorunlu eğitim çağındaki öğrencilerin temel eğitimlerini almaları amacıyla kamyonların kasalarının sınıf şekline dönüştürülmesiyle eğitim uygulamasının yapıldığı söylenebilir (Ağırkaya, 2010: 41).

Taşınan öğrenciler ile merkez okullardaki öğrenciler arasındaki başarı farkı önemli orandadır (Özkan, 1997). Normal ilköğretim okullarında, öğretmenlerin öğrencileri derse motive etmekte çektikleri zorluk, sabah ve öğleden sonraki derslerde eşit orandayken; taşımalı ilköğretim ve özellikle de YİBO öğrencilerinde öğleden sonra derse motive etmekte çekilen zorluk, sabah derslerinden daha yüksektir. Taşımalı öğrencilerde ev ödevlerini yapmaya vaktin kalmaması, yorgunluk, isteksizlik gibi nedenlerden dolayı zorluk çekenlerin oranı, yatılı ve normal ilköğretim öğrencilerinden daha yüksektir. Okuldayken rahatsızlık hisseden öğrencilerde en yüksek oran YİBO, ikinci taşımalı ve en düşük normal ilköğretimdedir (Yalçın, 2006:20, Taşdemir, 2010).

Taşımalı öğrencilerin yolculuktan sonra okula geldiklerinde yorgun oldukları ve bunun neticesinde derslerde dikkat ve ilginin azaldığı öğretmenler tarafından gözlemlenmektedir (Taşkıran, 2010; Karakütük, 1998; Kabaş, 2006; Recepoğlu, 2006; Yeşilyurt, Orak vd., 2007; Altunsaray, 1996; Yılmaz, 1998, Baş, 2001). Öğretmenler, çocukları özellikle ilk derse güdeleyememektedir (Ar1, 2003:114, Kefeli, 2005).

Öğleden sonra derse motive ise çok daha zordur. Hatta bazı öğrencilerin yorgunluğu evde de hissettikleri saptanmıştır (Taşdemir, 2010).

$\mathrm{Bu}$ çalışmanın amacı, dört temel dil becerisinden biri olan dinleme becerisinin ölçülmesinde taşımalı ve yerleşik öğrenciler arasında bir farklılı̆̆ın oluşup oluşmadığını ortaya koymaktır.

\section{Yöntem}

\subsection{Araştırma Grubu ve Örneklem}

Araştırmanın çalışma grubu 2011-2012 eğitim-öğretim yılında Trabzon İli Akçaabat ilçesindeki bir ilköğretim okulunda 6/A ve 6/B sinıflarında öğrenim gören 23'ü taşımalı 46 öğrenciden oluşmaktadır. Taşımalı ve yerleşik eğitim gören öğrenciler, sınıflar düzeyinde ayrılmamıştır.Ön test sonuçlarına göre başarı değişkeni açısından aralarında anlamlı farklılık bulunmayan öğrenciler gruplandırılmıştır. Taşımalılık değişkeninin dinleme becerisi üzerindeki etkisini deneysel olarak ortaya koymayı hedefleyen bu çalışmada yerleşik eğitim yapan öğrenciler kontrol 
grubu, taşımalı eğitim yapan öğrenciler ise deney grubu olarak adlandırılmıştır. Çalışmada bağımlı değişken başarıdır. 6/A ve 6/B sınıflarında taşımalı öğrenim gören 23 öğrenci deney grubu, 6/A ve 6/B sınıflarında yerleşik öğrenim gören 23 öğrenci ise kontrol grubu olarak tanımlanmıştır.

\subsection{Veri Toplama Araçları}

Türkiye'de okutulan öğretmen kılavuz kitapları toplanmıştır. $\mathrm{Bu}$ kitaplardan seçilen metinler arasından bir öyküleyici dinleme metni (Çocuk ile Geyik) altı alan uzmanının görüşü alınarak belirlenmiştir. Onaylanan metni anlamaya yönelik olarak dinleme amaç ve kazanımlarına uygun sorular hazırlanmıştır. Alan uzmanlarının gözden geçirdiği bu testler Trabzon ili Akçaabat ilçesi Mevlüt Selami Yardım İlköğretim Okulunun altıncı sınıfında öğrenim gören 40 öğrenciye uygulanmıştır. Uygulanan testlerin tamamı puanlanmış ve madde analizine sokulmuştur. Her soru maddesinin güçlük derecesi $(p)$ ve ayırt etme gücü (d) çıkarılmıştır. Önce $p$ değerleri 0,30 ile 0,70 arasındaki maddeler belirlenmiştir, bu aralıkların dışındaki maddeler testten çıkarılmıştır. Daha sonra d değerleri 0,40 ile 0,60 arasındaki maddeler belirlenmiştir. 20 maddelik test, 9 madde olarak son şeklini almıştır. Testin Güvenirlik Katsayısı (KR 20) 0,82 olarak saptanmışır.

\subsection{Deneysel İşlem Yolu}

Belirlenen deney ve kontrol gruplarına ilk olarak ön test uygulanmıştır. Test sonuçları Shapiro-Wilk normallik analizine tabii tutulmuştur. Normal dağılım gösterdiği saptanmış, bunun sonucunda Bağımsız T Testi yapılmıştır. Test sonucunda deney ve kontrol grupları arasında anlamlı bir farklılık gözlenmemiştir. (Anlamlılık sınırı 0, 05 olarak alınmıştır.)

Aralarında başarı yönünden anlamlı farklılık bulunmayan taşımalı (deney) ve yerleşik (kontrol) eğitim yapan gruplarda deneysel süreç ardışık iki ders saatidir. Sürecin birinci dersi; hazırlık, metin öncesi hazırlıklar ve zihinsel egzersizlerle işlenmiştir. İkinci derste metin $\mathrm{CD}^{\prime}$ den iki defa öğrencilere dinletilmiştir. Dinlemede öğrenciler gerekli notlarını almıştır. Ardından öğrencilerin dinleme metnine ait sorulara cevap vermesi istenmiştir. Yoklama öncesi, öğrencilerin dinleme metnine ait notları ortadan kaldırılmıştır. $\mathrm{Bu}$ işlemler dizisi, her iki gruba aynı süre içinde, aynı öğretmen tarafından, aynı yöntemlerle uygulanmıştır. Deneysel süreç, 6/A sınıfına 17 Kasım 2011'de ilk iki derste; 6/B sınıfına ise 18 Kasım 2011'de yine ilk iki derste uygulanmıştır. Çalışmada iki sınıf arasında başarı testine ilişkin 
bir bilgi alışverişine gidilmemesine özen gösterilmiştir. Sonuçlar, Bağımsız T Testi ile değerlendirilmiş ve yorumlanmıştır.

\subsection{Verilerin Analizi ve Kullanılan İstatistiksel Yöntemler}

$\mathrm{Bu}$ çalışma, 2011-2012 eğitim-öğretim yılının birinci döneminde Trabzon ili Akçaabat ilçesindeki ilköğretim okullarından birinde yürütülmüştür. Gruplar arasında başarı yönünden anlamlı farklılık olup olmadığını sınamak için ön test uygulanmış ve sonuçlar normallik analizine tabi tutulmuştur. Normallik analizinin sonucu doğrultusunda parametrik testlerden Bağımsız $\mathrm{T}$ Testi kullanılmıştır. Başarı testinden elde edilen sonuçlar da Bağımsız T Testi ile değerlendirilmiş ve yorumlanmıştır.

\section{Bulgular}

Deneysel süreç öncesi taşımalı ve yerleşik eğitim gören öğrencilerin başarı durumlarının anlamlı farklılık gösterip göstermediğini görmek ve süreçte ilk olarak kullanılacak testleri belirlemek amacıyla normallik analizi yapılmıştır. Örneklem 50'den küçük olduğu için Shapiro-Wilk normallik testi kullanılmıştır. Verilerin analizinde ise SPSS 15,0 programı kullanılmıştır. Analiz sonucu her iki grubun p değeri anlamlllık değeri olan 0,05 'ten büyük çıkmıştır. Bu verilerden hareketle grupların karşılaştırılmasında parametrik testlerden Bağımsız T Testi kullanılmıştır. Normallik testinin sonuçları ve ön test Bağımsız T Testi sonuçları tablo 1 ve 2 'de verilmiştir:

Tablo1: Normallik Testi

\begin{tabular}{|c|c|c|c|c|}
\hline \multirow{4}{*}{ 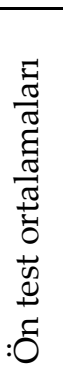 } & \multirow{2}{*}{ Eğitim Şekli } & \multicolumn{3}{|c|}{ Shapiro-Wilk } \\
\hline & & Statistic & $\mathrm{df}$ & $\mathrm{P}$ \\
\hline & Taşımalı Grup & ,980 & 23 & ,900 \\
\hline & Yerleşik Grup & 961 & 23 & ,474 \\
\hline
\end{tabular}


Tablo 2: Ön Test Sonuçlarına Göre Grupların Karşılaştırılması

\begin{tabular}{|c|c|c|c|c|c|c|}
\hline \multirow{3}{*}{ 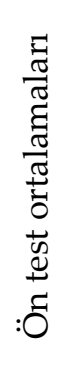 } & Gruplar & $\mathrm{n}$ & $\begin{array}{l}\text { Aritmetik } \\
\text { Ortalama }\end{array}$ & $\begin{array}{c}\text { Standart } \\
\text { Sapma }\end{array}$ & $\mathrm{t}$ & p \\
\hline & TaşımalıGrup & 23 & 70,65 & 11,085 & 2,311 & \multirow{2}{*}{285} \\
\hline & $\begin{array}{l}\text { Yerleşik } \\
\text { Grup }\end{array}$ & 23 & 74,70 & 14,069 & 2,934 & \\
\hline
\end{tabular}

p $>0,05$ olduğu için deneysel süreç öncesinde iki grup arasında anlamlı bir farklılık bulunamamıştır. Bu sonuç, iki grubun deneysel bir çalışma için elverişli olduğu şeklinde yorumlanabilir. Aralarında anlamlı farklılık bulunmayan grupların başarı ortalaması, süreç sonrası yerleşik grup lehine farklılaşmıştır. $(\mathrm{p}<0,05)$ Bu değişim, öğrenim şeklinden kaynaklanmaktadır. Süreç sonrasında başarı durumu şu şekildedir:

Tablo 3: Deneysel Süreç Sonrası Grupların Karşılaştırılması

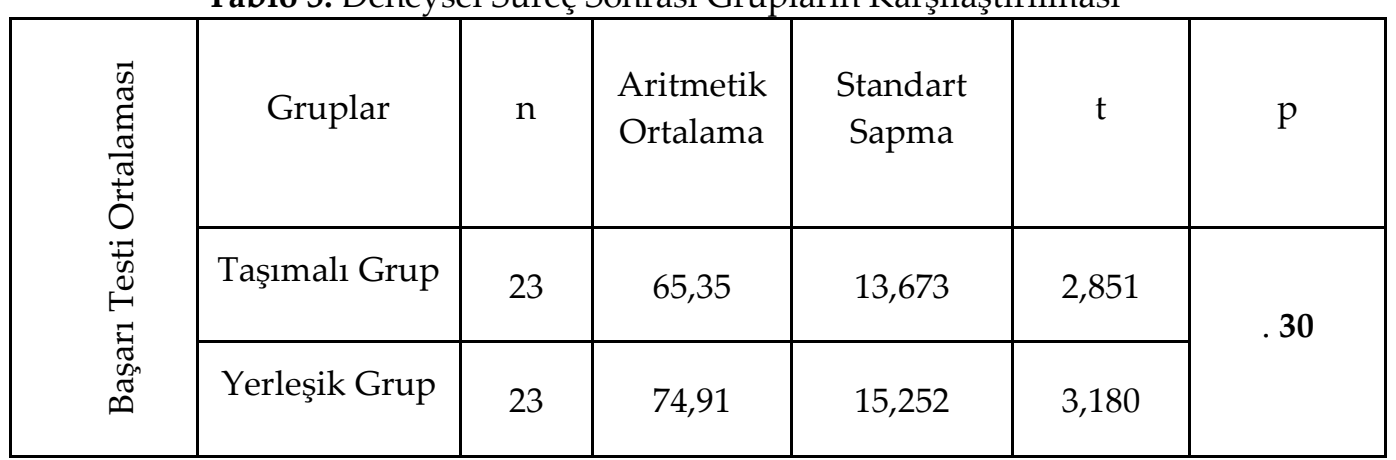

Yerleşik eğitim yapan grubun aritmetik ortalaması ise 74, 91 iken, taşımalı grubun aritmetik ortalaması 65, 35'tir. İki grup arasında 9, 56'lık bir fark vardır. Bu sonucun nedeni eğitim şekli değişkenidir. Her iki grup öğrencileri arasında başlangıçta anlamlı bir değişiklik görülmezken aynı deneysel süreçten geçen iki gruptan süreç sonrası sonuçlarına bakıldığında taşımalı grubun dezavantajlı olduğu ortaya çıkmıştır. Uygulama işlemleri, zihin faaliyetleri açısından en verimli zaman dilimi olan ilk iki derste gerçekleştirilmiştir; fakat taşımalı eğitim yapan öğrenciler, taşımanın verdiği fiziki ve mental yorgunluk nedeniyle performans kaybı yaşamışlardır. 
Çalışmadan elde edilen sonuçlara göre, taşımalılık değişkeni, öğrenci başarısını etkileyen önemli bir faktör olarak karşımıza çıkmaktadır.

\section{Tartışma Sonuç ve Öneriler}

Türkçe öğretimi, anlama ve anlatma becerilerinin geliştirilmesi esasına dayanmaktadır. Anlama becerileri okuma ve dinleme; anlatma becerileri ise konuşma ve yazma temel dil becerileridir. $\mathrm{Bu}$ dil becerileri arasında dinleme, çocuğun ilk ana dili becerisidir. Anne karnındayken gelişmeye başlayan dinleme becerisi, okul öncesi döneminde doğal ortamda gelişir, okulda öğretim programlarıyla üst düzeylere ulaşır. Atasözlerinden deyimlere geniş bir yelpazede milletin folklorik hazinesinde önemine vurgu yapılan dinleme becerisi 2005 Türkçe Öğretim Programı ile birlikte kendisine müstakil bir öğrenme alanı açma başarısını kazanmıştır. Bilindiği üzere dinleme becerisi günlük yaşamda en fazla kullanılan beceridir. Gerek okulda gerekse hayatın diğer safhalarında en etkili öğrenme yollarından biridir. Bu itibarla etkili dinlemenin öğrencilerin akademik ve sosyal başarıları üzerindeki etkisi göz ardı edilemez. Sözlü iletişim sürecinde etkili anlama ve cevap verme yeteneği olan dinleme, konuşulan kelimelere dikkat etmeyi, seslerin yanı sıra onları anlamayı gerektirir. Her gün hiç düşünmeden, çevremizde olup biteni anlamlandırmak için kullandığımız bir dil becerisi olan dinleme işitmeyi, anlamayı, anlaşılan bilgileri önceki bilgilerle bütünleştirmeyi ve gerekirse cevap vermeyi içeren aktif bir süreçtir.

Mulcahy (1997), öğrenci velileriyle yaptığı çalışmada taşımalı eğitimin başta yorgunluk ve hastalık olmak üzere farklı sorunlara yol açabileceğini, Zars (1998) veSpence (2000) taşımalı eğitimin öğrencilerin akademik başarıları üzerinde olumsuz etkiler yaratabileceğini; Jimerson (2007) uzun taşımasürelerinin öğrencilerin ders dışı etkinliklere katılımını olumsuz yönde etkileyeceğini dile getirmektedir.

Şan (2010) , öğrenci velilerinin “Gün içinde yaşadığ1 yorgunluk çocuğunuzun başarısını olumsuz etkiliyor mu?" sorusuna \% 65 oranında evet cevabını verdiğini saptamıştır. Taşkıran (2010) Antalya'da taşımalı eğitim yapan dört okulda yaptığ 1 çalışmada yerleşik öğrencilerin akademik başarılarının taşımalı öğrencilerden yüksek olmasını, öğrencilerin yorgunluğuna ve motivasyon eksikliğine bağlarken Taşbaşı(2011)öğrencilerin sabahçı olmasının ve okula gelmeden önce köy işlerinde çalışmasının yorgunluğun artmasına neden olduğunu dile getirmektedir. Turan (2011), Zonguldak ilini örneklem olarak aldığ çalışmada taşımalı öğrencilerin yerleşik öğrencilere nazaran başarı 
düşüklüğünü ulaşım, beslenme ve okula uyum problemleriyle açıklamaktadır.

Araştırmadan elde edilen verilere göre başarı durumları eşit olan taşımalı ve yerleşik öğrencilerin dinleme başarı testinden aldıkları sonuçlar, yerleşik öğrencilerin lehine anlamlı olarak farklı çıkmıştır. Taşımalı öğrencilerin taşıma sürecinde yaşadığı fiziksel ve zihinsel yorgunluk, öğrenme başarılarını olumsuz yönde etkilemektedir. Yapılan araştırmalarda (Yalçın, 2006; Taşdemir, 2010) bu yorgunluğun özellikle öğlen sonrasında zirveye çıktı̆̆ 1 dile getirilmektedir.

Çalışmanın sonuçları cinsiyet bazında incelendiğinde, yıl sonu başarısında yerleşik eğitim gören kız öğrencilerle taşımalı eğitim gören kız öğrenciler arasında anlamlı farklılık bulunmazken, erkeklerde yerleşik eğitim lehine anlamlı farklılık görülmüştür. Yine SBS'ye göre değerlendirmede 6 . ve 7 . sınıftaki yerleşik eğitim gören kız öğrencilerin puan ortalaması, taşımalı eğitim gören kız öğrencilerden daha yüksektir.

$\mathrm{Bu}$ sonuçlardan hareketle, taşımalı öğrencilerin bulunduğu okullarda aktif dinleme gerektiren dil, matematik, fen ve sosyal bilgiler derslerinin sabah saatlerinde; beden eğitimi, müzik ve resim gibi spor ve sanat derslerinin ise öğleden sonra yapılması ve aynı zamanda yazılı yoklamaların sabah saatlerinde yapılması daha faydalı olabilir.

Ayrıca, Büyükkaragöz ve Şahin (1995)'in de belirttiği gibi, taşımalı eğitim yapan okulların öğrencilerin ikamet ettikleri yerlere $15 \mathrm{~km}$ 'den daha uzak olmamasına dikkat edilebilir ve böylece eğitimdeki imkân ve fırsat eşitliği sağlanmış olur.

\section{Kaynakça}

Ağırkaya, A., (2010).Taşımalı Eğitim Uygulamasında Öğretmenler ve Öğrencilerin Karşılaştıkları Güçlükler (Yayımlanmamış Yüksek Lisans Tezi). Selçuk Üniversitesi Eğitim Bilimleri Enstitüsü.

Ailes, R., (1996). Mesaj Sizsiniz Kendiniz Olun İstediğinizi Elde Edin. (Çev. Alev Önder). İstanbul: Sistem Yayınları.

Akyol, H., (2010). Türkçe Öğretim Yöntemleri. Ankara: PegemA Yayınları.

Altunsaray, A., (1996). Taşımalı Ilköğretim Uygulamasının Değgerlendirilmesi (Yayımlanmamış Yüksek Lisans Tezi). Balıkesir Üniversitesi Sosyal Bilimler Enstitüsü. .

Aras, B., (2004). İlköğretimde Dinleme Anlama Becerisinin Geliştirilmesi (Yayımlanmamış Yüksek Lisans Tezi). Gazi Üniversitesi Eğitim Bilimleri Enstitüsü. 
Arı, A., (2000). Normal, Taşımalı ve Yatılı Illköğretim Okullarımın Karşılaştırılması (Yayımlanmamış Yüksek Lisans Tezi). Afyon Kocatepe Üniversitesi Sosyal Bilimler Enstitüsü.

Arı, A., (2003). Taşımalı İlköğretim Uygulaması: Uşak Örneği. Gazi Eğitim Fakültesi Dergisi, Cilt 23, Sayı 1, 101-115.

Aytan, T.,(2011). Aktif Öğrenme Tekniklerinin Dinleme Becerisi Üzerindeki Etkileri (Yayımlanmamış Doktora Tezi). Selçuk Üniversitesi Eğitim Bilimleri Enstitüsü

Baş, M., (2001). Taşımalı İlköğretimde Karşılaşılan Sorunlar Bolu İli Örneği (Yayımlanmamış Yüksek Lisans Tezi). Abant İzzet Baysal Üniversitesi Sosyal Bilimler Enstitüsü.

Büyükkaragöz, S. ve Şahin, H., (1995). Taşımalı İlköğretim Uygulamaları. Eğitim ve Bilim, Nisan, Cilt 19. Say. 96.

Cihangir, Z., (2004). Kişilerarası İletişimde Dinleme Becerisi. Ankara: Nobel Yayınevi.

Çelebi, H. M., (2008). İlköğretim 6, 7 ve 8. Sinıf Öğrencilerinin Olay ve Düşünce Yazılarına Göre Dinleme Becerilerinin Değerlendirilmesi (Yayımlanmamış Yüksek Lisans Tezi). Muğla Üniversitesi Sosyal Bilimler Enstitüsü.

Çelenk, S., (2005). İlk Okuma Yazma Programı ve Öğretimi. Ankara: Anı Yayınları.

Çelikbaş, K. A.,(2010). Anlama/Dinleme Stratejilerinin Kullanımı ile Dinlediğini Anlama Düzeyi Arasındaki İlişki (Yayımlanmamış Yüksek Lisans Tezi). Yüzüncü Yıl Üniversitesi Sosyal Bilimler Enstitüsü.

Doğan, Y., (2007).ilköğretim İkinci Kademede Dil Becerisi Olarak Dinlemeyi Geliştirme Çalışmaları (Yayımlanmamış Doktora Tezi). Gazi Üniversitesi Eğitim Bilimleri Enstitüsü.

Ergin, A. ve Birol, C., (2000). Ĕ̆itimde İletişim. Ankara: Anı Yayıncılık. Gürgen, İ., (2008). Türkçe Öğretimi. Eskişehir: Anadolu Üniversitesi Yayinları.

Hampleman, R., (1958). Comparison of Listening and Reading Comprehension Ability of 4th and 6th Grade Pupils. Elementary English. XXXI, 49.

Healy, J. M., (1999). Çocuğunuzun Gelişen Akl-Doğumdan Ergenliğe Öğrenme ve Beyin Gelişimi. (Çev.: Ayşe Bilge Dicleli). İstanbul: Boyner Holding Yayınları.

Jalongo, M. R., (1995). Promoting Active Listening in the Classroom. Childhood Education, 72. 1, pp. 13-18. 
Jimerson, L., (2007). Traveling by School Bus in Consolidated Districts in West Virginia. A Publication of the Policy Program of the Rural School and Community Trust. http://www.eric.ed.gov/PDFS/ED499440.pdf (Erişim tarihi: 07 /07/2010)

Johnson, K. O., (1951). The Effect of Classroom Training upon Listening Comprehension. The Journal of Communication,I, 58.

Kabaş, N., (2006). Taşımalı İlköğretim Uygulamasında Karşılaşılan Sorunlar: Bolu İli Örneği (Yayımlanmamış Yüksek Lisans Tezi). Abant İzzet Baysal Üniversitesi Sosyal Bilimler Enstitüsü.

Kantemir, E., (1997). Yazılı ve Sözlü Anlatım. Ankara: Ankara Üniversitesi Eğitim Fakültesi Yayınları.

Kaplan, H., (2003). İlköğretim 6. Sinıf Öğrencilerinin Dinleme Becerileri Üzerine Bir Araştırma (Yayımlanmamış Yüksek Lisans Tezi). Gazi Üniversitesi Eğitim Bilimleri Enstitüsü.

Karatürk; M., (1998). Taşımalı İlköğretim Uygulaması ve Sorunları: Sincan İlçesi Örneği. Eğitim ve Bilim Dergisi, Cilt 22, Sayı 108, 16-21.

Kaygas, N., (2002). Üniversite Son Sinıf Öğrencilerinin Okuma ve Dinleme Sonucu Anladıkların Yazıl Anlatma Becerileri (Yayımlanmamış Yüksek Lisans Tezi). Çanakkale On Sekiz Mart Üniversitesi Sosyal Bilimler Enstitüsü.

Kefeli, S., (2005). Taşımalı İlköğretim ve Sorunları (Yayımlanmamış Yüksek Lisans Tezi). Abant İzzet Baysal ÜniversitesiSosyal Bilimler Enstitüsü.

Koç, N., (2003). Dinleme Becerilerini Kazandırma Yöntemlerinin Uygulanması (Yayımlanmamış Yüksek Lisans Tezi). Çanakkale On Sekiz Mart Üniversitesi Sosyal Bilimler Enstitüsü.

Köklü, S., (2003). Türkçe Öğretiminde 7. ve 8. Sinıf Öğrencilerine Dinlediğini Anlama Davranışıın Kazandırılmasına Dramatizasyonun Etkisi (Yayımlanmamış Yüksek Lisans Tezi). Marmara Üniversitesi Eğitim Bilimleri Enstitüsü.

Kurt, B., (2008). Çocuk Edebiyatı Ürünlerinin Temel Dil Becerisi Olarak Dinlemenin Gelişimine Etkisi (Yayımlanmamış Yüksek Lisans Tezi). Gazi Üniversitesi Eğitim Bilimleri Enstitüsü.

MEB (2005). Taşımalı Illköğretim Yönetmeliği. Resmi Gazete, 25796.

MEB (2005). Taşımalı İlköğretim Uygulamaları. http://iogm. meb. gov. tr

MEB (2012). 02. 08. 2012 tarihli ve B. 08. 0. DHG. 0. 05. 00. 00. 802-03, 2012/32 sayll genelgehttp://dhgm. meb. gov. tr/meb_iys_dosyalar/2012_08/02035459_2012_32. pdf (Erişim tarihi: 20/06/2012). 
Moore, K. D., (t. y). Öğretim Becerileri (Çev. : Nizamettin Kaya). Ankara: Turhan Kitabevi.

Mulcahy, D, M. (1997). Rural Education Reform: The Consultation Process. http://www.eric.ed.gov/PDFS/ED413152.pdf.( Erişim tarihi: 20/07/2013 )

Özbay, M., (2005). Bir Dil Becerisi Olarak Dinleme Eğitimi. Ankara: Akçă̆ Yayınları.

Özdemir, E., (1987).ilkokul Öğretmenleri İçin Türkçe Öğretimi Kılavuzu. İstanbul: İnkılâp Kitabevi.

Özkan, N., (1997). Taşımalı İlköğretim Uygulamasında Sayısal Gelişmeler, Güçlükler ve Çözüm Örnekleri (Yayımlanmamış Yüksek lisans tezi). Hacettepe Üniversitesi Sosyal Bilimler Enstitüsü.

Recepoğlu, E., (2006). İlköğretim Uygulamasında Taşıma Merkezi Olan İlköğretim Okullarının Sorunları, Çankırı, Karabük ve Kastamonu İli Örneğgi (Yayımlanmamış Yüksek Lisans Tezi). Gazi Üniversitesi Sosyal Bilimler Enstitüsü.

Robertson, A. K., (2004). Etkili Dinleme (Çev.: E. Sabri Yarmalı). İstanbul: Hayat Yayınları.

Rost, M., (1994). Introducing Listening. London: Penguin English Applied Linguistics.

Spence, B. (2000). Long School Bus Rides: Their Effect on School Budgets, Family Life and Student Achievment.Office of Educational Research and Improvement, Washington, DC.

Şan, A. (2012). Illköğretimde Taşımalı Eğitim Öğrencilerinin Sorunları. (Yayımlanmamış Yüksek Lisans Tezi). Dokuz Eylül Üniversitesi Eğitim Bilimleri Enstitüsü.

Wolff, F. I., Marsnik, N. C., Tacey, W. S. and Nichols, R. G., (1983). Perceptive Listening. New York: CBS College Publishing.

Taşbaşı, A.N. (2011).Taşımalı Ĕ̆itim ve Toplumsal Sorunlar.(Yayımlanmamış Yüksek Lisans Tezi). Atatürk Üniversitesi Sosyal Bilimler Enstitüsü.

Taşdemir, M., (2010). Taşımal Ĕ̆itime İlişkin Veli Görüşleri, Şile İlçesi Örneği (Yayımlanmamış Yüksek Lisans Tezi). Yeditepe Üniversitesi Sosyal Bilimler Enstitüsü.

Taşkıran, B., (2010). Taşımalı Eğitim Merkezlerinde Öğrenci Başarısının Çeşitli Değişkenler Açısından Karşılaştırılması (Yayımlanmamış Yüksek Lisans Tezi). Akdeniz Üniversitesi Sosyal Bilimler Enstitüsü.

Temur, T., (2001). Dinleme Becerisi. Konu Alanı Ders Kitabı İnceleme Kılavuzu Türkçe 1-8. Ankara: Nobel Yayınları. 
Turan, S. (2011). Taşımalı İlköğretim Uygulamasında Karşılaşılan Güçlükler (Yayımlanmamış Yüksek Lisans Tezi) Hacettepe Üniversitesi Eğitim Bilimleri Enstitüsü.

Yalçın, K. Y.,(2006). Yerleşik ve Taşımalı Eğitim Yapan İlköğretim Okullarındaki Öğrencilerin Toplumsallaşmasında Beden Eğitimi ve Sporun Önemi (Yayımlanmamış Yüksek Lisans Tezi). Dumlupınar ÜniversitesiSosyal Bilimler Enstitüsü.

Yaşlı, A., (2001).Öğrenmede Empatik Dinleme ve Öğrenme Güdülenmesine Etkisi(YayımlanmamışYüksek Lisans Tezi). Ege Üniversitesi Sosyal Bilimler Enstitüsü. .

Yeşilyurt, M., Orak, S., Tozlu, N., Uçak, A. ve Sezer, D., (2007). İlköğretimde Taşımalı Eğitim Araştırması: Van İl Merkezi Örneği. Elektronik Sosyal Bilimler Dergisi, Cilt 6, Sayı 19, 197-213.

Yıldırım, H., (2007). İlköğretim Ü̧̈üncü Sinıf Öğrencilerinin Dinleme Becerileri Üzerine Bir Araştırma (Yayımlanmamış Yüksek Lisans Tezi). Abant İzzet Baysal Üniversitesi Sosyal Bilimler Enstitüsü.

Yılmaz, İ., (2007).Türkçe Öğretiminde Dinleme Becerisini Geliştirmeye Yönelik Önerilen Etkinliklerin Değerlendirilmesi (Yayımlanmamış Yüksek lisans Tezi). Niğde Üniversitesi Sosyal Bilimler Enstitüsü.

Yangın, B., (1998). Dinlediğini Anlama Becerisini Geliştirmede ELVES Yönteminin Etkisi (Yayımlanmamış Doktora Tezi). Hacettepe Üniversitesi Sosyal Bilimler Enstitüsü.

Yazkan, M., (2000). İlköğretim Okullarının I. Kademesinde Dinlediğini Anlama Davranışının Kazandırılmasına Dramatizasyonun Etkisi (YayımlanmamışYüksek Lisans Tezi). Marmara Üniversitesi Eğitim Bilimleri Enstitüsü.

Zars, B. (1998). Long Rides, Tough Hides: Enduring long school bus rides.www.ruralchallengepolicy.org.zars_busing.htrn. (Erişim tarihi 20.07.2013) 